\title{
Lysosomal changes in the hemocytes of the freshwater mussel Dreissena polymorpha experimentally exposed to lead and zinc
}

\author{
Laure Giamberini*, Jean Claude Pihan \\ Centre de Recherches Ecologiques de l'Université de Metx, Equipe d'Ecotoxicologie, BP 4116, F-57040 Metz, France
}

\begin{abstract}
This study examines the structural changes of the lysosomal system of the hemocytes of the zebra mussel Dreissena polymorpha experimentally exposed to lead and zinc. A cytochemical technique which demonstrated acid phosphatase activity as a lysosomal marker was used on blood cell monolayers. The results indicate that the effects of both metals on hemocytic lysosomes were variable and that no marked linear relationship between lysosomal changes and metal concentration and exposure time was observed. Hemocytes of exposed zebra mussels exhibited enlarged and/or more numerous lysosomes. The use of the lysosomal changes in the hemocytes as a biomarker of contaminant exposure is discussed.
\end{abstract}

KEY WORDS: Freshwater mussel - Heavy metals · Hemocytes - Lysosomal changes - Biomarker

\section{INTRODUCTION}

Aquatic organisms are able to concentrate in their soft tissues a wide range of contaminants occurring in their environment. Therefore, they have been used as sentinel organisms in the monitoring of environmental pollution. In these studies, particular attention has been given to marine filter-feeding bivalves (Phillips \& Rainbow 1988, Browler 1989, Cossa 1989) and, most often, only the xenobiotic body burdens have been taken into account. During the last decade, several authors have shown the importance of assessing the biological effects of pollutants in biomonitoring programs (Bayne 1989, Livingstone et al. 1989, Widdows \& Donkin 1989, Narbonne et al. 1991, VeldhuizenTsoerkan et al. 1991, Depledge et al. 1995). In this context, numerous markers of pollution effects and/or exposure have been developed at different levels of the biological organization (Bayne 1985, Galgani et al. 1992, Regoli 1992, Cajaraville et al. 1995a, Regoli \& Principato 1995, Sole et al. 1995). Cellular markers can offer rapid and sensitive indicators of adaptive

·E-mail: giamb@sciences.univ_metz.fr responses to environmental contamination, before pollutant-induced injury manifests at the level of the whole organism (Moore 1985, Cajaraville et al. 1995b). In many cases, the earliest detectable changes are associated with subcellular organelles such as lysosomes (Moore 1985). Lysosomes are involved in a broad spectrum of both physiological and pathological functions (Holtzman 1976, Moore 1982, Cheng 1983). Lysosomes are also involved in accumulation and detoxication of both metallic and organic xenobiotics (George 1980, George \& Viarengo 1985, Viarengo et al. 1985, 1988). Many microanalytical investigations have demonstrated the occurrence of trace metals in the lysosomal-vacuolar system of different cell types in bivalve molluscs (Schulz-Baldez 1977, George et al. 1978, Lowe et al. 1979, Ballan-Dufrançais et al. 1985, Nigro et al. 1992). In molluscs, the digestive gland represents one of the main target organs of pollutant accumulation. Therefore, using various technical approaches, the responses of the digestive cell lysosomal system have received the principal attention in pollution assessment in marine ecosystems. Numerous field and experimental studies have shown that various environmental stressors (metallic and organic xenobiotics, thermal, hypoxia and salinity stress, oxygen- 
free radicals) caused 2 main types of general stress responses in mollusc digestive gland cells: reduction in lysosomal membrane stability and enlargement of lysosomes (Moore 1976, Lowe et al. 1981, Patel \& Patel 1985, Viarengo et al. 1987, Lowe 1988, Moore 1988, Cajaraville et al. 1989, Lowe \& Clarke 1989, Marigomez et al. 1989, Winston et al. 1991, Regoli 1992, Etxeberria et al. 1994, Krishnakumar et al. 1994, Lowe \& Pipe 1994, Svenden \& Weeks 1995).

On the other hand, the biological tools to assess the health condition of organisms are lacking for the monitoring of freshwater ecosystems. Previous investigations have reported the use of the freshwater mussel Dreissena polymorpha as a bioindicator of water pollution (Kraak et al. 1991, Mersch \& Pihan 1993). In zebra mussel, as in other bivalve species, the hemocytes are rich in lysosomal hydrolases and are involved in metal transport and detoxication (Giamberini 1993). In this context, the purpose of the present study was to evaluate cytochemically the lysosomal responses in the hemocytes of $D$. polymorpha experimentally exposed to high concentrations of an essential metal $(\mathrm{Zn})$ or of a non-essential metal $(\mathrm{Pb})$.

\section{MATERIALS AND METHODS}

Zebra mussel exposure. Mature specimens of Dreissena polymorpha (18 to $22 \mathrm{~mm}$ in length) were collected at a reference location and acclimatized to the experimental conditions for $1 \mathrm{wk}$. The intoxication experiment was conducted at $14 \pm 1^{\circ} \mathrm{C}$ on a $16 \mathrm{~h}$ light: $8 \mathrm{~h}$ dark cycle. Fifty zebra mussels were placed on tiles to which they could become attached, kept in $9 \mathrm{l}$ tanks, and exposed to lead chloride $\left(\mathrm{PbCl}_{2}\right)$ at concentrations of 400 and $800 \mu \mathrm{g} \mathrm{l}^{-1}$ or to zinc chloride $\left(\mathrm{ZnCl}_{2}\right)$ at concentrations of 500 and $1000 \mu \mathrm{g} \mathrm{l}^{-1}$ for $5 \mathrm{wk}$. Lethal concentrations have been established for $D$. polymorpha populations in The Netherlands (Kraak et al. 1994). These are for lead: $\mathrm{LC}_{50}(8 \mathrm{wk})=2330 \mu \mathrm{g} \mathrm{l^{-1 }}, \mathrm{LC}_{50}$ $(10 \mathrm{wk})=497 \mu \mathrm{g} \mathrm{I}^{-1} ;$ and for zinc: $\mathrm{LC}_{50}(3 \mathrm{wk})=4293 \mu \mathrm{g}$ $\mathrm{I}^{-1}, \mathrm{LC}_{50}(10 \mathrm{wk})=1065 \mu \mathrm{g} \mathrm{\textrm {I } ^ { - 1 }}$. The control group received only dechlorinated tap water. Turnover of the tank volume was achieved by means of a peristaltic pump. $\mathrm{PbCl}_{2}$ and $\mathrm{ZnCl}_{2}$ stock solutions were continuously introduced into the tanks by a second pump to yield the desired concentration of metals. Food was continuously added in the form of a monospecific suspension of the algae Chlamydomonas variabilis, which is readily assimilated by D. polymorpha (Ten Winkel \& Davids 1982). Four zebra mussels were sampled after 7, 21 and 35 treatment days from each experimental group.

Hemolymph collection and hemocyte monolayers. Hemolymph was obtained by making a notch near the posterior margin of the mussel shell in the dorsal portion. A needle was inserted between the valves, and the hemolymph was withdrawn from the posterior adductor muscle sinus. Portions of hemolymph samples were placed onto a cleaned glass slide, in a moist chamber, and the hemocytes were allowed to settle for $15 \mathrm{~min}$ at room temperature. Subsequently, the hemocytes were fixed for 5 min with $1.25 \%$ glutaraldehyde (grade Ii Sigma Chemical Co., St. Louis, MO, USA) in cacodylate buffer solution (0.025 M, pH 7.4) and rinsed with buffer solution.

Enzyme cytochemistry. Acid phosphatases (ACP) (E.C.3.1.3.2) were demonstrated by the azo-dye coupling method (Diagnostic kit 386, Sigma Chemical Co.) using naphthol AS-BI phosphate as substrate and Fast Garnet GBC as coupler (Goldberg \& Barka 1962). The change in the presence and relative amounts of ACP following the exposure to metals was assessed according to the method of Moore \& Gelder (1985) modified for the present study. To indicate the relative degree of reactivity, 200 hemocytes were examined on each slide and assigned to 1 of 4 categories: class 1 ( 0 to $25 \%$ of the endoplasm filled with positive granules), class 2 (25 to $50 \%$ of the endoplasm filled with positive granules), class 3 (50 to $75 \%$ of the endoplasm filled with positive granules) and class 4 (75 to $100 \%$ of the endoplasm filled with positive granules). The degree of reactivity reflects the relative number and/or size of positively staining granules in hemocytes and not the amount of final reaction per granule. The data were then expressed as percentages.

Statistical analysis. Data of the control and experimental groups were compared using the Mann-Whitney $U$-test.

\section{RESULTS}

The morphology of the hemocytes belonging to the 4 classes defined in the present study is illustrated in Fig. 1. Granules reacting for ACP activity occur in the endoplasm. The percentage of the hemocytes in each class, indicating the amount of positively staining granules in cells, are reported for the zebra mussels non-exposed (Fig. 2A) and exposed to $400 \mu \mathrm{g} \mathrm{I}^{-1}$ (Fig. 2B) and $800 \mu \mathrm{g} \mathrm{l}^{-1}$ (Fig. 2C) of $\mathrm{Pb}$ for $35 \mathrm{~d}$. In general terms and for the whole exposure time, the number of hemocytes with $\ll 50 \%$ of the endoplasm containing positive granules (classes 1 and 2) tends to decrease, whereas the number of hemocytes with $\gg 50 \%$ of the endoplasm occupied by lysosomes (classes 3 and 4 ) tends to increase in exposed mussels. The differences between the control and exposed mussels are significant for the hemocytes in classes 1 and 3 (Fig, 2B, C). In these classes, the lyso- 


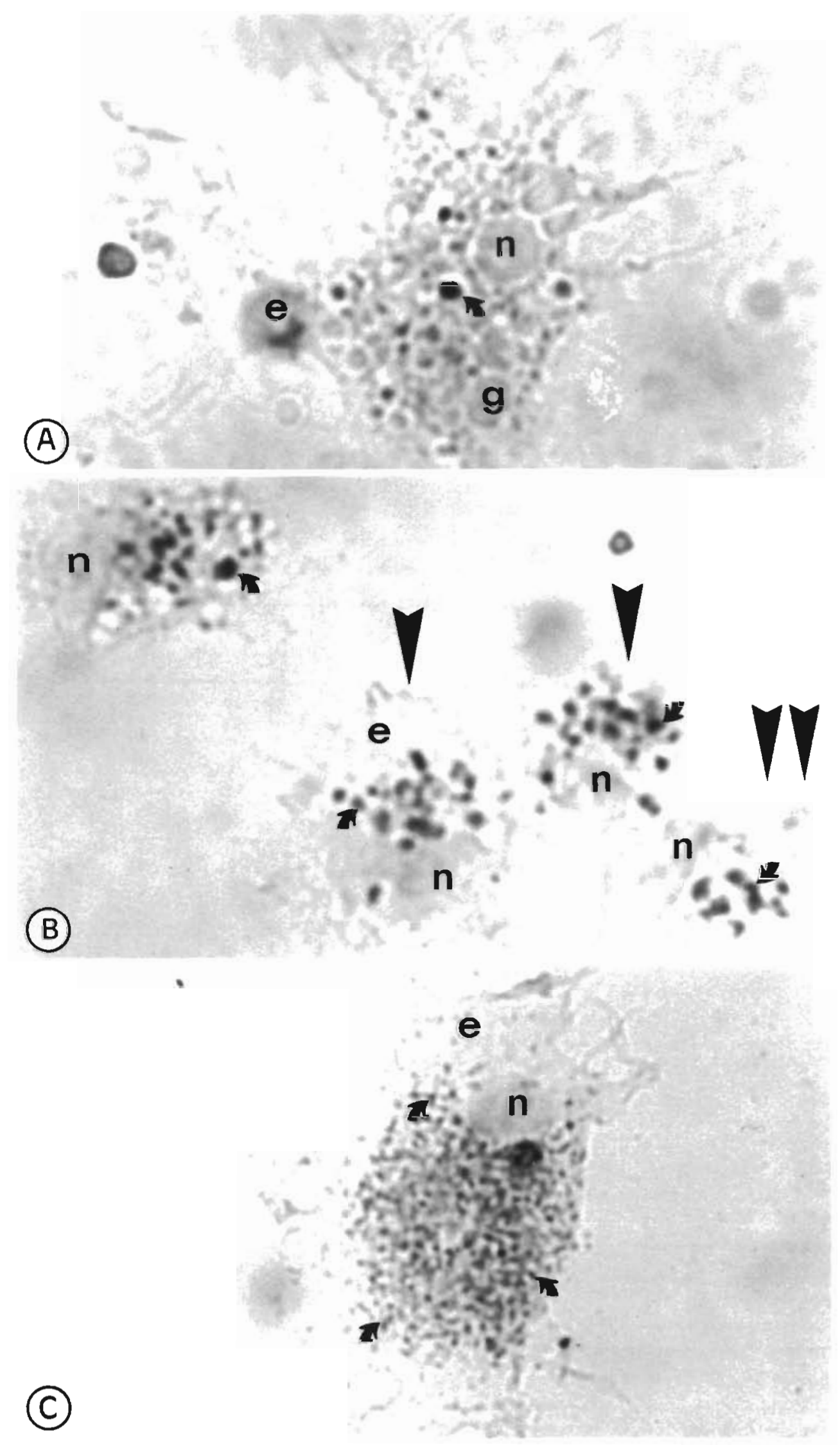

Fig. 1. Dreissena polymorpha. Acid phosphatase reactivity (small curved arrows) in the endoplasmic granules in the 4 classes of hemocytes. (A) Hemocytes of class 1 (B) Hemocytes of class 2 (double arrowheads) and of class 3 (simple arrowheads). (C) Hemocytes of class 4. Abbreviations: $\mathrm{e}=$ ectoplasm; $g$ = endoplasmic granules; $\mathrm{n}=$ nucleus; $\mathrm{p}=$ pseudopod 

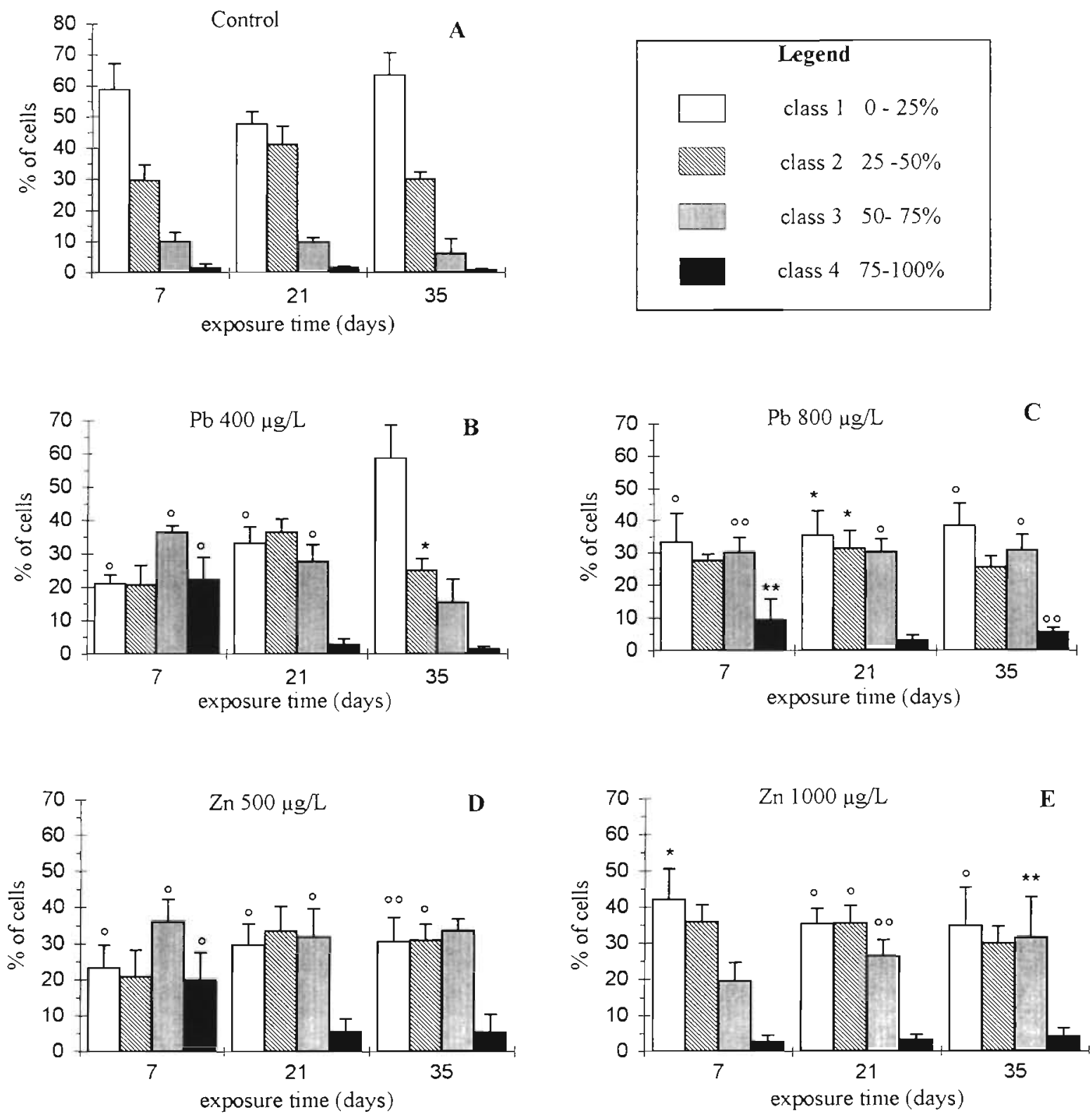

Fig. 2. Dreissena polymorpha. Percentages of hemocytes in 4 classes (mean $\pm \mathrm{SD}$ ). (A) Non-exposed, exposed to (B) $400 \mu \mathrm{g} \mathrm{l}^{-1}$ or to (C) $800 \mu \mathrm{g} \mathrm{\textrm {I } ^ { - 1 }}$ of $\mathrm{Pb}$, and exposed to (D) $500 \mu \mathrm{g} \mathrm{l^{-1 }}$ or to (E) $1000 \mu \mathrm{g} \mathrm{l^{-1 }}$ of $\mathrm{Zn}$. ${ }^{\star} \mathrm{p}<0.05{ }^{* \star} \mathrm{p}<0.02 ;{ }^{\circ} \mathrm{p}<0.01 ;{ }^{\circ 0} \mathrm{p}<0.001$

somal changes are more marked at short times $(7 \mathrm{~d})$ for mussels exposed to the lower lead concentration (Fig. 2B). Nevertheless, the response seems to be modified with time, and the differences between control and exposed groups are not significant at the end of the experiment ( $35 \mathrm{~d}$ ). The proportion of the hemocytes in class 4 (Fig. 2B, C) remains low, but tends to increase with lead concentration. The large increase of hemocyte percentage in class 4 for mussels exposed to $400 \mu \mathrm{g} \mathrm{l}^{-1}$ of $\mathrm{Pb}$ for $7 \mathrm{~d}$ (Fig, 2B) is difficult to explain since this response is observed neither for the other exposure times nor for the higher lead concentration. However, in class 4, the response of the lysosomal system is more evident at short exposure time for the zebra mussels exposed to both concentrations of lead. The experimental exposure of zebra mussels to zinc induces qualitatively the same lysosomal changes in the 4 classes of hemocytes (Fig. 2D, E).

The results indicate that experimental exposure to $\mathrm{Pb}$ or $\mathrm{Zn}$ provokes an increase in lysosomal number and/or size in the hemocytes of zebra mussels which does not always show a linear dependence with the time or with the dose of exposure. 


\section{DISCUSSION}

This preliminary experimental and cytochemical study shows that sublethal concentrations of lead and zinc induce lysosomal changes in the hemocytes of Dreissena polymorpha. Zebra mussels exposed to both metals exhibit enlarged and/or more numerous lysosomes. Enlargement of lysosomes, whether or not this is associated with an increase in lysosome number, seems to be a non-specific stress biomarker (Cajaraville et al. 1995a, b, Etxeberria et al. 1995). We report here, for the first time, this type of alteration in blood cells, but enlarged lysosomes have been observed in the digestive cells of both bivalve and gastropod molluscs exposed to a wide variety of environmental stress. It is difficult to compare our results since the effects of lead on biochemical functions have rarely been studied (Gnassia-Barelli \& Romeo 1993), particularly in the case of freshwater invertebrates (Rainbow \& Dallinger 1992). The exposure to sublethal concentration of lead $(500 \mathrm{ppm})$ induced in the earthworm Eisenia foetida a destabilisation of chloragosomal membranes leading to the partial release of their acid phosphatases into the cytosol (Cancio et al. 1995). Bolognani-Fantin \& Franchini (1991) reported an increase of both lysosome number and enzyme activity in the neurons of Viviparus ater experimentally exposed to acute concentrations of lead. Under laboratory conditions, metals such as $\mathrm{Cu}$ and $\mathrm{Cd}$ caused enlargement of lysosomes in the digestive gland of Mytilus edulis (Lowe \& Clarke 1989) and Littorina littorea (Marigomez et al. 1989). A mixture of metals, such as $\mathrm{Fe}, \mathrm{Mn}, \mathrm{Cu}, \mathrm{Zn}$ and particularly those rich in $\mathrm{Pb}$, led to the same results in natural populations of the marine mussels Mytilus galloprovincialis (Regoli 1992) and $M$. edulis (Lowe 1988). In these studies, an increase in lysosome size was concomitant with a decrease in their numbers. This suggests a process of smaller secondary lysosomes fusing to form large autolysosomes (Lowe et al. 1981) which are associated with membrane destabilization or increased permeability resulting in reduced latency of lysosomal hydrolases (Moore 1985, Regoli 1992). Our results are similar to those of Etxeberria et al. (1994), who report an increase in both size and number of the lysosomes in the digestive cells of $M$. galloprovincialis exposed to $\mathrm{Zn}$, $\mathrm{Cu}$ or $\mathrm{Cd}$ under field and experimental conditions. The lysosomal alterations they observed did not always show a linear dependence with metal concentrations, and they did not report different impacts of metals which do or do not have a biological function. The heterogeneity of the lysosomal responses when exposed to both organic (Moore 1988, Cajaraville et al. 1995a) and metallic (Suresh \& Mohandas 1990) xenobiotics has often been stressed. The enlargement of lysosomes and/or the increase of their numbers are better illustrated by classes 1 and 3 . However, the variability observed here in the hemocytic lysosomal responses still remains difficult to explain and further studies are necessary to fully understand these structural changes The effects of both metals, nonessential (Pb) and essential ( $\mathrm{Zn})$, follow the same general pattern. Zebra mussels can regulate $\mathrm{Zn}$ up to $191 \mu \mathrm{g} \mathrm{l}^{-1}$, but capacity decreases with exposure time. On the contrary, lead cannot be regulated and is accumulated (Kraak et al. 1994). The short-term responses observed under lead exposure could correspond to an adaptive response. This may be related to the detoxication function of the lysosomes. However, the total number of hemocytes of animals exposed both to $\mathrm{Pb}$ or $\mathrm{Zn}$ did not show significant changes during this contamination experiment (Giambérini 1993). It is generally accepted that bivalve hemocytes are involved in metal transport from uptake to excretion organs. In cells, metals (and especially lead) are sequestrated and immobilized in inert form in lysosomes before excretion (Viarengo 1989, Nott 1993).

Lysosomal enlargement in the mollusc digestive gland could be induced not only by metals but also by various organic xenobiotics such as PAH or PCB (Lowe 1988, Moore 1988, Lowe \& Clarke 1989), oil-derived hydrocarbons (Lowe et al. 1981, Cajaraville et al. 1995a) and 1-naphthol (Cajaraville et al. 1989). These studies concluded that lysosomal enlargement represented a good indicator of general environmental stress.

Various techniques, such as microdensitometry or stereology, principally in the digestive gland cells, have been used to assess lysosomal changes (membrane destabilization, number and size variations). Other cell types, such as blood cells, rich in lysosomes (Cheng 1981) and involved in internal defense mechanisms and metal accumulation have been only rarely investigated. Using biochemical techniques, Pickwell \& Steinert (1984) and Suresh \& Mohandas (1990) concluded that copper caused destabilization of lysosomal membrane or hypersynthesis of acid hydrolases in bivalve hemocytes before their release into the hemolymph. Very recently, lysosomal responses have been determinated in blood cells of several species of molluscs by in vitro tests using neutral red retention (Lowe et al. 1995, Svedsen \& Weeks 1995). Due to several characteristics of bivalve hemocytes (richness in lysosomes, the presence of several acid hydrolases which are cytochemically demonstrable and an isolated stade), measurements of the lysosomal structure in this cell type have an enormous potential for the assessment of pollutant effects (Cajaraville et al. 1995b).

In conclusion, these results indicate that the hemocytic lysosomes of zebra mussels exposed to lead and 
zinc exhibit structural changes. Thus, we could consider the response of the vacuolar-lysosomal system in the hemocytes of Dreissena polymorpha as a potential biomarker for exposure to freshwater pollution. However, several further investigations are necessary before validation of this biomarker. First, an automated image analysis will improve the objectivity and the precision of the method. Moreover, parameters such as size and number can be identified separately and more rapidly. In addition, experimental approaches with different and more realistic metal concentrations will be useful to precisely measure the sensitivity of the response. The sensitivity of this potential biological marker must be tested in natural conditions where mixtures of contaminants and various environmental stresses occur. Finally, to obtain an integrated evaluation of organism health, the lysosomal changes will be extremely useful in concert with other biomarkers at different levels of the biological organization, such as the gametogenetic index, and the scope-for-growth and body condition index.

Acknowledgements. The authors are grateful to Dr Daniel P. Molloy, New York State Museum, for comments on the manuscript translation.

\section{LITERATURE CITED}

Ballan-Dufrançais C, Jeantet AY, Feghali C, Halpern S (1985) Physiological features of heavy metal storage in bivalves digestive cells and amoebocytes: EMPA and factor analysis of correspondences. Brol Cell 53:283-292

Bayne BL (1985) Ecological consequences of stress. In: Bayne $B L$, Brown DA, Burns $K$, Dixon DR, Ivanovici $A$, Livingstone DR, Lowe DM, Moore MN, Stebbing ARD, Widdows $J$ (eds) The effects of stress and pollution on marine animals. Praeger Publishers, New York, p 141-160

Bayne BL (1989) Measuring the biological effects of pollution: The mussel watch approach. Water Sci Technol 21: $1089-1100$

Bolognani-Fantin AM, Franchini A (1991) Ultracytochemical modifications in ganglia of Viviparus ater subsequent experimental lead intoxication. Proc 10th Int Malacol Congr (Tübingen 1989):181-185

Browler JA (1989) Introduction: aquatic organisms as indicators of environmental pollution. Water Resour Bull 24: $927-929$

Cajaraville MP, Abascal I, Etxeberria M, Marigomez I (1995a) Lysosomes as cellular markers of environmental pollution: time and dose-dependent responses of the digestive lysosomal system of mussels after petroleum hydrocarbon exposure. Environ Toxicol Wat Qual 10:1-8

Cajaraville MP, Marigomez JA, Angulo E (1989) A stereological survey of lysosomal structure alterations in Littorina littorea exposed to 1-naphthol. Comp Biochem Physiol 93C (2): $231-237$

Cajaraville MP, Robledo $Y_{1}$ Etxeberria M, Marigomez I (1995b) Cellular biomarkers as useful tools in the bıological monitoring of environmental pollution molluscan digestive lysosomes. In: Cajaraville MP (ed) Cell biology in environmental toxicology. University of Basque Country Press Service, Bilbo, p 29-55

Cancio I, Gwynn I, Ireland MP, Cajaraville MP (1995) The effects of sublethal lead exposure on the ultrastructure and on the distribution of acid phosphatase activity in the chloragocytes of earthworms (Annelida, Oligochaeta). Histochem J 27:965-973

Cheng TC (1981) Bivalves. In: Ratcliffe NA, Rowley AF (eds) Invertebrate blood cells. Academic Press, London, p 231-300

Cheng TC (1983) The role of lysosomes in molluscan inflammation. Am Zool 23:129-144

Cossa D (1989) A review of the use of Mytilus spp. as quantitative indicators of cadmium and mercury contamination in coastal waters. Oceanol Acta 12:417-423

Depledge MH, Aagaard A, Györkös P (1995) Assessment of trace metal toxicity using molecular, physiological and behavioural biomarkers. Mar Pollut Bull 31:19-27

Etxeberria M, Cajaraville MP, Marigomez I (1995) Changes in digestive cell lysosomal structure in mussels as biomarkers of environmental stress in the Urdaibai estuary (Biscay coast, Iberian peninsula). Mar Pollut Bull 30(9):599-603

Etxeberria M, Sastre I, Cajaraville MP, Marigomez I (1994) Digestive lysosome enlargement induced by experimental exposure to metals $(\mathrm{Cu}, \mathrm{Cd}$ and $\mathrm{Zn})$ in mussels collected from a zinc-polluted site. Arch Environ Contam Toxicol 27: $338-345$

Galgani $F$, Bocquene $G$, Truquet $P$, Burgeot $T$, Chiffoleau JF, Claisse D (1992) Monitoring of pollutant biochemical effects on marine organisms of the French coasts. Oceanol Acta 15 (4) $355-364$

George SG (1980) Correlation of metal accumulation in mussels with the mechanisms of uptake, metabolism and detoxification: a review. Thalassia Jugosl 16:347-365

George SG, Pirie BJS, Cheyne AR, Coombs TL, Grant PT (1978) Detoxication of metals by marine bivalves: an ultrastructural study of the compartmentation of copper and zinc in the oyster Ostrea edulis. Mar Biol 45:147-156

George SG, Viarengo A (1985) A model for heavy metal homeostasis and detoxification in mussels. In: Vernberg FG, Thurberg FP, Calabrese A, Vernberg WB (eds) Marine pollution and physiology. Recent advances. University of South Carolina Press, Columbia, p 125-143

Giamberini L (1993) Etude des mécanismes de transport et detoxication des métaux lourds chez la moule d'eau douce Dreissena polymorpha. Rôle des hémocytes et des organes du système excréteur (histologie, ultrastructure, microanalyse). PhD thesis, University of Metz

Gnassia-Barelli M, Romeo M (1993) Some aspects of lead ecotoxicology in the marine environment. Aquat Toxicol 26: $163-170$

Goldberg AF, Barka T (1962) Acid phosphatase activity in human blood cells. Nature 189:297

Holtzman E (1976) Lysosomes: a survey. Springer-Verlag, Wien

Kraak MSH, Scholten MCT, Peeters WHM, de Kock WC (1991) Biomonitoring of heavy metals in the western European rivers Rhine and Meuse using the freshwater mussel Dreissena polymorpha. Environ Pollut 74:101-114

Kraak MSH, Wink YA, Stuijfzand SC, Buckert-de Jong MC, de Groot CJ, Admiraal W (1994) Chronic ecotoxicity of $\mathrm{Zn}$ and $\mathrm{Pb}$ to the zebra mussel Dreissena polymorpha. Aquat Toxicol 30:77-89

Krishnakumar PK, Casillas E, Varanasi U (1994) Effect of environmental contaminants on the health of Mytilus edulis from Puget Sound, Washington. USA. I. Cytochemical measures of lysosomal responses in the digestive cells 
using automatic image analysis. Mar Ecol Prog Ser 106: 249-261

Livingstone DR, Moore MN, Widdows J (1989) Ecotoxicology: biological effects measurements on molluscs and their use in impact assessment. Pollution of the North Sea: an assessment. Springer-Verlag, Berlin, p 624-637

Lowe DM (1988) Alterations in cellular structure of Mytilus edulis resulting from exposure to environmental contaminants under field and experimental conditions. Mar Ecol Prog Ser 46:91-100

Lowe DM, Clarke KR (1989) Contaminant-induced changes in the structure of the digestive epithelium of Mytilus edulis. Aquat Toxicol 15:345-358

Lowe DM, Moore MN, Clarke KR (1979) The cytochemical distributions of zinc ( $\mathrm{Zn}$ II) and iron (Fe III) in the common mussel, Mytilus edulis, and their relationship with lysosomes. J Mar Biol Assoc UK 59:851-858

Lowe DM, Moore MN, Clarke KR (1981) Effects of oil on digestive cells in mussels: quantitative alterations in cellular and lysosomal structure. Aquat Toxicol 1:213-226

Lowe DM, Pipe RK (1994) Contaminant induced lysosomal membrane damage in marine mussel digestive cells: an in vitro study. Aquat Toxicol 30:357-365

Lowe DM, Soverchia C, Moore MN (1995) Lysosomal membrane responses in the blood and digestive cells of mussels experimentally exposed to fluoranthene. Aquat Toxicol 33:105-112

Marigomez JA, Vega MM, Cajaraville MP, Angulo E (1989) Quantitative responses of the digestive-lysosomal system of winkles to sublethal concentrations of cadmium. Cell Mol Biol 35:555-562

Mersch J, Pihan JC (1993) Simultaneous assessment of environmental impact on condition and trace metal availability in zebra mussels Dreissena polymorpha transplanted into the Wiltz River, Luxembourg. Comparison with the aquatic moss. Arch Environ Contam Toxicol 25:353-364

Moore CA. Gelder SR (1985) Demonstration of lysosoma] enzymes in hemocytes of Mercenaria mercenaria (Mollusca: Bivalvia). Trans Am Microsc Soc 104(3):242-249

Moore MN (1976) The quantitative cytochemical effects of three metal ions on a lysosomal hydrolase of a hydroid. J Mar Biol Assoc UK 56:995-1005

Moore MN (1982) Lysosomes and environmental stress. Mar Pollut Bull 13 (2):42-43

Moore MN (1985) Cellular responses to pollutants. Mar Pollut Bull 16:134-139

Moore MN (1988) Cytochemical responses of the lysosomal system and NADPH-ferrihemoprotein reductase in molluscan digestive cells to environmental and experimental exposure to xenobiotics. Mar Ecol Prog Ser 46:81-89

Narbonne JF, Ribera D, Michel X, Raoux C, Garrigues $P$. Monod JL, Lemaire P, Galgani F, Romeo M, Salaün JP, Lafaurie $M$ (1991) Indicateurs biochimiques de contamination de l'environnement marin: étude comparative en mer Mediterrannée. Océanis 17(3):257-275

Nigro M, Orlando E, Regoli F (1992) Ultrastructural localization of metal binding sites in the kidney of the Antarctic scallop Adamussium colbecki. Mar Biol 113:637-643

Nott JA (1993) Cytology of pollutant metals in marine invertebrates: a review of microanalytical applications. Scanning Microsc 5(1): 191-205

Patel S, Patel B (1985) Effect of environmental parameters on lysosomal marker enzymes in the tropical blood clam. Anadara granosa. Mar Biol 85:245-252

Phillips DJH, Rainbow PS (1988) Bannacles and mussels as biomonitors of trace elements: a comparative study. Mar Ecol Prog Ser 49:83-93

Pickwell GV, Steinert SA (1984) Serum biochemical and cellular responses to experimental cupric ion challenge in mussels. Mar Environ Res 14:245-265

Rainbow PS, Dallinger R (1992) Metal uptake, regulation and excretion in freshwater invertebrates. In: Dallinger $R$, Rainbow PS (eds) Ecotoxicology of metals in invertebrates Chap 7. SETAC Special Publications Series, Lewis Publishers, Boca Raton, FL, p 119-132

Regoli F (1992) Lysosomal responses as a sensitive stress index in biomonitorng heavy metal pollution. Mar Ecol Prog Ser 83:63-69

Regoli F, Principato G (1995) Glutathione, glutathione-dependent and antioxidant enzymes in mussel, Mytilus galloprovincialis, exposed to metals under field and laboratory conditions: implications for the use of biochemical biomarkers. Aquat Toxicol 31:143-164

Schulz-Baldez M (1977) Lead transport in the common mussel Mytilus edulis. In: Mc Lusky DS, Berry AJ (eds) Physiology and behavior of marine organisms. Pergamon Press, Oxford, p 211-219

Solé M, Porte C, Albaigés J (1995) The use of biomarkers for assessing the effects of organic pollution in mussels. Sci Total Environ 159:147-153

Suresh K, Mohandas A (1990) Effect of sublethal concentrations of copper on hemocyte number in bivalves. J Invertebr Pathol 55:325-331

Svendsen C, Weeks JM (1995) The use of a lysosome assay for the rapid assessment of cellular stress from copper to the freshwater snail Viviparus contectus (Millet). Mar Pollut Bull 31(1-3): 139-142

Ten Winkel EH, Davids C (1982) Food selection by Dreissena polymorpha Pallas. Freshwat Biol 12:553-558

Veldhuizen-Tsoerkan MB, Holwerda DA, de Bont AMT, Smaal AC, Zandee DI (1991) A field study on stress indices in the sea mussel, Mytilus edulis: application of the 'stress approach' in biomonitoring. Arch Environ Contam Toxicol 21:497-504

Viarengo A (1989) Heavy metals in marine invertebrates: mechanisms of regulation and toxicity at the cellular level. Rev Aquat Sci 1:295-317

Viarengo A, Canesi L, Pertica M, Mancinelli G, Orunesu M, Mazzucotelli A, Bouquegneau JM (1988) Biochemical characterization of a copper-thionein involved in Cu accumulation in the lysosomes of the digestive gland of mussels exposed to the metal. Mar Environ Res 24:163-166

Viarengo A, Moore MN, Mancinelli G, Mazzucotelli A, Pipe RK, Farrar SV (1987) Metallothioneins and lysosomes in metal toxicity and accumulation in marine mussels: the effect of cadmium in the presence and absence of phenanthrene. Mar Biol 94:251-257

Viarengo A, Moore MN, Pertica M, Mancinelli G, Zanicchi G (1985) Detoxification of copper in the cells of the digestive gland of mussel: the role of lysosomes and thioneins. Sci Total Environ 44:135-145

Widdows J, Donkin P (1989) The application of combined tissue residue chemistry and physiological measurement of mussels (Mytilus edulis) for the assessment of environmental pollution. Hydrobiologia 188/189:455-461

Winston GW, Moore MN, Straatsburg I, Kirchin MA (1991) Decreased stability of digestive gland lysosomes from the common mussel Mytilus edulis L. by in vitro generation of oxygen-free radicals. Arch Environ Contam Toxicol 21 $401-408$ 